\title{
Implementation of Learning Methods and Levels of Self Regulated Learning in Writing
}

\author{
Mutiarani Pionera; I Nyoman Sudana Degeng; Utami Widiati; Punaji Setyosari \\ Universitas Negeri Malang, East Java, Indonesia
}

http://dx.doi.org/10.18415/ijmmu.v6i2.761

\begin{abstract}
The research approach used by researchers is a quantitative approach. This study aims to examine whether there are differences in English text writing skills of students who learning using CIRC and PWIW learning methods as well as Students with high and low levels of Self-Regulated Learning. The sample in this study were the 80 seventh grade learners of MTsN 1 Palangkaraya, Central Borneo, Indonesia, in 2018/2019 academic year involved in this study. They then were divided into two classes randomly sampled to be the experimental group and the control group. Data analysis using the independent sample $t$ test. The research findings obtained the pretest value showed no difference in students 'writing skills learned by the CIRC method (68.525) and PWIW (70.525) while the posttest value test showed that there were differences in the students' writing skills learned by the CIRC method more higher equal to 79.20 compared to PWIW amounted to 69.52. The findings of the study show that students with low self-regulated learning have a higher value of English text writing skills 84.58 compared to students with high self-regulated learning at 74.33 .
\end{abstract}

Keywords: Learning Methods; Self Regulated; Writing

\section{Introduction}

In the educational environment, the implementation of cooperative learning is able to show enthusiasm, curiosity and involvement of learners (students) in accepting their learning assignments which are not only beneficial for them in the group but for the students themselves in the overall class (Shafiee \& Khavaran, 2017). However, teachers still face difficulties in handling a variety of unexpected problems that arise in each group of students, as well as the need for a longer time in organizing learning. Other difficulties are also found in assessing the assignments of students considering they must be joined in one study group, so teachers need to make additional assessments of the progress of each student's learning and encourage them to take part in self-evaluation and reflection of their progress.

Difficulties or constraints that occur in the implementation of cooperative learning above can basically be overcome by choosing the right cooperative learning method, coincide with the student learning outcomes to be achieved. Among the various forms of cooperative learning that have been developed, the Cooperative Integrated Reading and Composition (CIRC) has a number of aspects and work steps that pay attention to activities as well as evaluation of each student's learning progress even though they are incorporated into a group. According to Slavin (1991), CIRC is a learning that activates students to learn together with the aim of ensuring all students are actively involved when learning takes place; students form groups that discuss each other and are responsible for each other to complete the 
requested learning assignments. CIRC relies on students' reading skills in terms of vocabulary mastery and appropriate spelling to improve their writing skills.

Besides CIRC, there are other learning methods which according to some studies also highlight the relationship of reading and writing skills. Picture-Word Inductive Model (PWIM) is a basic learning model of vocabulary mastery which also highlights reading-writing skills. Calhoun (1999), PWIM is used by teachers to direct students in groups or individuals in activities to investigate words (which are presented in an image), add words in activities to read and write vocabulary, find phonetic forms and word structures, and make observations and analyzes in reading, writing, understanding, and composing writing.

Jiang and Perkins (2013) stated that there were no studies that revealed the effectiveness of PWIM specifically in improving language skills, especially vocabulary mastery, so researchers felt the need to investigate the implementation of PWIM in learning to find out how it affects the process of reading and writing students, certainly to improve their writing skills. From the above explanation, it is necessary to examine whether there are differences in text writing skills between groups of students who are taught by the Cooperative Integrated Reading and Composition and groups of students who are taught with Picture-Word Inductive Models and high and low self-regulated learning students.

\section{Research Methods}

The research approach used by researchers is a quantitative approach. Wherein the quantitative approach is research whose data is in the form of numbers and analyzed by statistical analysis to find answers from the problem formulation of a study. While the method used by researchers is the experimental method. There were 80 seventh grade learners of MTsN 1 Palangkaraya, Central Borneo, Indonesia, in 2018/2019 academic year involved in this study. They then were divided into two classes randomly sampled to be the experimental group and the control group. Learners included in the experimental group learned together in a team formation. Data analysis in this study was independent sample $t$ test. This test was used to determine whether exist or not the average/mean difference between the two groups of unrelated samples. If there are differences, which average/mean is higher. Data used is usually interval or ratio scale.

\section{Results and Discussion}

\section{Description of Research Result Data}

\section{Description of Pre-test Results of Student Writing Skills}

The pre-test in the form of an essay test of writing skills was given before the treatment in both groups of students. In other words, both the Cooperative Integrated Reading and Composition (CIRC) and Picture-Word Inductive Model (PWIM) have not been implemented as learning methods for students in both groups. The results of the descriptive analysis between the CIRC and PWIW classes are shown in Table 1 below:

Table 1. Pre-test scores for Student Learning Outcomes Writing Skills based on the Implementation of Learning Methods

\begin{tabular}{|ll|l|l|l|}
\hline & Method & Mean & Std. Deviation & Std. Error Mean \\
\hline Pretest & CIRC & 68.5250 & 7.49354 & 1.18483 \\
& PWINP & 70.5250 & 10.69864 & 1.69160 \\
\hline
\end{tabular}

Table 1. shows that students in the treatment/experimental class before the CIRC is implemented obtain an average score of pre-test results reaching 68.53 with a standard deviation of 7.49 , while students 
in the control class before the PWIM are implemented get an average of pre-test results reaching 70.525 with a standard deviation of 10.699. The results of the pre-test scores showed no difference in students' writing skills. But these results need to be tested by using statistical hypothesis testing to obtain valid conclusions. The results of the pre-test results above are then analyzed using the t test to get accurate information about how significant the writing skills of students are in the two classes. The results of the unpaired t-test analysis (independent sample $t$ test) with the help of the SPSS program to test the difference in the results of the pre-test with the learning method are presented in Table 2. as follows:

Table 2. T Test Results for Pretest Value of Student Writing Skills

\begin{tabular}{|c|c|c|c|c|c|c|c|c|c|c|}
\hline \multicolumn{11}{|c|}{ Independent Samples Test } \\
\hline & & \multicolumn{2}{|c|}{$\begin{array}{c}\text { Levene's Test for Equality of } \\
\text { Variances }\end{array}$} & \multicolumn{7}{|c|}{ t-test for Equality of Means } \\
\hline & & \multirow[b]{2}{*}{$\mathrm{F}$} & \multirow[b]{2}{*}{ Sig. } & \multirow[b]{2}{*}{$t$} & \multirow[b]{2}{*}{$d f$} & \multirow[b]{2}{*}{ Sig. (2-tailed) } & \multirow{2}{*}{$\begin{array}{c}\text { Mean } \\
\text { Difference }\end{array}$} & \multirow{2}{*}{$\begin{array}{l}\text { Std. Error } \\
\text { Difference }\end{array}$} & \multicolumn{2}{|c|}{$\begin{array}{l}\text { 95\% Confidence Interval of the } \\
\text { Difference }\end{array}$} \\
\hline & & & & & & & & & Lower & Upper \\
\hline Pretes & $\begin{array}{l}\text { Equal variances } \\
\text { assumed }\end{array}$ & 1,931 &, 169 &,- 968 & 78 &, 336 & $-2,00000$ & 2,06527 & $-6,11164$ & 2,11164 \\
\hline & $\begin{array}{l}\text { Equal variances not } \\
\text { assumed }\end{array}$ & & &,- 968 & 69,843 &, 336 & $-2,00000$ & 2,06527 & $-6,11922$ & 2,11922 \\
\hline
\end{tabular}

Table 2. Test of Independent Samples Test obtained the value of Sig Levene's Test equal to 0,169, with a significance value greater than the standard error of 5\% $(p>0.05)$, so it was concluded that there was no difference in variance in the pre-test scores of English text writing skills between the two groups of students, so that it could be tested with an independent t-test assuming a homogeneous variance of data (equal variance assumed).

The next test uses an unpaired t test (independent sampel $t$ test), examine whether there are differences in the value of the pretest of English text writing skills. Table 4.2, the results of the independent $t$ test obtained a significance value of $0.336\left(p>0.05\right.$, accepted $\left.\mathrm{H}_{0}\right)$, which means that there is no significant difference in the pre-test scores of English text writing skills between groups of students in the treatment class before CIRC is implemented with groups of students in the control class before the PWIM is implemented.

Description of Student Learning Outcomes based on the Implementation of Learning Methods and Levels of Self-Regulated Learning

Student learning outcomes from the implementation of the Cooperative Integrated Reading and Composition (CIRC) and Picture-Word Inductive Model (PWIM) with different levels of self-regulated learning (high and low) were recapitulated to get an overview of the learning outcomes from the research subjects after receiving the treatment. Student learning outcomes based on the implementation of learning methods and the level of self-regulated learning are shown in Table 3.

Table 3. The Value of Student Learning Outcomes based on the Implementation of Learning Methods and Levels of Self-Regulated Learning

\begin{tabular}{|l|l|l|l|l|}
\hline \multirow{4}{*}{ SRL } & \multicolumn{4}{|l|}{ Learning Methods } \\
\cline { 2 - 5 } & CIRC & Std. dev. & MWIM \\
\cline { 2 - 5 } & Mean & 4.90 & 68.65 & 7.83 \\
\hline Low & 84.58 & 7.65 & 70.17 & 7.52 \\
\hline High & 74.33 & Std. dev. \\
\hline
\end{tabular}

Source: Primary Data Processed, 2019 
Table 3. The results of the descriptive analysis show that the students who are taught use the CIRC method with a low level of self-regulated learning obtaining the highest average score of 84.58 with a standard deviation of 4.90, while students with a high level of self-regulated learning obtain an average learning value of 74.33 with a standard deviation of 7.65. Students who study using the PWIM method with a low level of self-regulated learning obtain an average score reaching 68.65 with a standard deviation of 7.83, while students with a high level of self-regulated learning obtain an average learning value of 70.17 with a standard deviation of 7.52 .

These results indicate a difference from the application of both learning methods and the level of self-regulated learning of students towards student learning outcomes. Descriptively, the highest student scores were found in students from the group learned through the CIRC method with a low level of selfregulated learning, while the lowest student scores were found in students from the group learned through the PWIM method with a low level of self-regulated learning. However, students who are taught through these two methods tend to have almost the same value at a high level of self-regulated learning. The values of student learning outcomes are then again analyzed to obtain accurate information about how significant students' writing skills are at the level of high and low self-regulated learning after the implementation of the CIRC and PWIM learning methods.

The results of the unpaired t-test analysis (independent sample $t$ test) which examined the differences in the value of student learning outcomes based on the implementation of the two learning methods are presented in Table 4.

Table 4. T Test Results for Student Values with CIRC and PWIM Learning Methods

\section{Group Statistics}

\begin{tabular}{|ll|l|l|l|l|}
\hline & Method & $\mathrm{N}$ & Mean & Std. Deviation & Std. Error Mean \\
\hline Results & CIRC & 40 & 79.20 & 8.370 & 1.323 \\
& PWIM & 40 & 69.52 & 7.789 & 1.232 \\
\hline
\end{tabular}

\begin{tabular}{|c|c|c|c|c|c|c|c|c|c|c|}
\hline \multicolumn{11}{|c|}{ Independent Samples Test } \\
\hline & & \multicolumn{2}{|c|}{$\begin{array}{l}\text { Levene's Test for Equality of } \\
\text { Variances }\end{array}$} & \multicolumn{7}{|c|}{ t-test for Equality of Means } \\
\hline & & \multirow[b]{2}{*}{$\mathrm{F}$} & \multirow[b]{2}{*}{ Sig. } & \multirow[b]{2}{*}{$t$} & \multirow[b]{2}{*}{ df } & \multirow[b]{2}{*}{ Sig. (2-tailed) } & \multirow{2}{*}{$\begin{array}{l}\text { Mean } \\
\text { Difference }\end{array}$} & \multirow{2}{*}{$\begin{array}{l}\text { Std. Error } \\
\text { Difference }\end{array}$} & \multicolumn{2}{|c|}{$\begin{array}{l}95 \% \text { Confidence Interval of the } \\
\text { Difference }\end{array}$} \\
\hline & & & & & & & & & Lower & Upper \\
\hline & $\begin{array}{l}\text { Equal variances } \\
\text { assumed }\end{array}$ & .214 &, 645 & 5,352 & 78 &, 000 & 9,675 & 1,808 & 6,076 & 13,274 \\
\hline & $\begin{array}{l}\text { Equal variances not } \\
\text { assumed }\end{array}$ & & & 5,352 & 77,599 &, 000 & 9,675 & 1,808 & 6,076 & 13,274 \\
\hline
\end{tabular}

The results of the analysis in Group Statistics above show that there are 40 students in the class who implement CIRC has an average value of English writing skills equal to 79.20 while in the class implementing PWIM has an average value of English text writing skills equal to 69.53. As for the output table of Independent Samples Test obtained the value of Sig Levene's Test amounted to 0.645, the significance value is greater than 0.05 , and it can be concluded that there are no variance differences in the value of English texts writing skills between groups of students with the CIRC and PWIM learning methods, so that it can be tested with an independent t-test assuming a homogeneous variance of data (equal variance assumed).

In knowing the difference in learning outcomes, then conducted the test statistically using unpaired t-test (independent sample t-test). Table 4 shows the results of the independent $\mathrm{t}$ test for the 
value of English text writing skills between groups of students taught by the CIRC and PWIM methods having a significance value of $0.000\left(p<0.05\right.$, accepted $\left.\mathrm{H}_{1}\right)$, which means that there are significant differences in the value of English text writing skills between groups of students who are taught by both methods. Table 4.4 in the Group Statistics also shows that students taught with CIRC have better English text writing skills than students taught with PWIM.

Furthermore, the results of unpaired t-test analysis (independent sample $t$ test) were conducted to test the differences in the value of student learning outcomes based on the level of self-regulated learning presented in Table 5.:

Table 5 T Test Results for Student Values based on the Self-Regulated Learning Level

Group Statistics

\begin{tabular}{|ll|r|r|r|r|}
\hline & SRL & $N$ & Mean & Std. Deviation & $\begin{array}{c}\text { Std. Error } \\
\text { Mean }\end{array}$ \\
\hline Hasil & Rendah & 36 & 77,06 & 10,387 & 1,731 \\
& Tinggi & 44 & 72,16 & 7,953 & 1,199 \\
\hline
\end{tabular}

\begin{tabular}{|c|c|c|c|c|c|c|c|c|c|c|}
\hline \multicolumn{11}{|c|}{ Independent Samples Test } \\
\hline & & \multicolumn{2}{|c|}{$\begin{array}{c}\text { Levene's Test for Equality of } \\
\text { Variances }\end{array}$} & \multicolumn{7}{|c|}{ t-test for Equality of Means } \\
\hline & & \multirow[b]{2}{*}{$\mathrm{F}$} & \multirow[b]{2}{*}{ Sig. } & \multirow[b]{2}{*}{$t$} & \multirow[b]{2}{*}{$d f$} & \multirow[b]{2}{*}{ Sig. (2-tailed) } & \multirow{2}{*}{$\begin{array}{c}\text { Mean } \\
\text { Difference }\end{array}$} & \multirow{2}{*}{$\begin{array}{l}\text { Std. Error } \\
\text { Difference }\end{array}$} & \multicolumn{2}{|c|}{$\begin{array}{c}\text { 95\% Confidence Interval of the } \\
\text { Difference }\end{array}$} \\
\hline & & & & & & & & & Lower & Upper \\
\hline & $\begin{array}{l}\text { Equal variances } \\
\text { assumed }\end{array}$ & 3,272 &, 074 & 2,388 & 78 &, 019 & 4,896 & 2,051 & .814 & 8,979 \\
\hline & $\begin{array}{l}\text { Equal variances not } \\
\text { assumed }\end{array}$ & & & 2,325 & 64,544 &, 023 & 4,896 & 2,106 &, 690 & 9,103 \\
\hline
\end{tabular}

Table 5. The results in Group Statistics show that 36 students with low self-regulated learning have an average value of text writing skills equal to 77.06, then high self-regulated learning has an average value of 72.16 for text writing skills. The test result of Independent Samples Test obtained the Sig Levene's Test value of 0.074 , the significance value is greater than 0.05 , it can be concluded that there is no difference in the variance of the value of text writing skills between groups of students with low and high self-regulated learning, so that it can be tested with an independent t-test assuming a homogeneous variance of data.

To find out the existence of these differences, a statistical test was performed using an unpaired $t$ test (independent sampel t test). Table 5 shows the results of the independent $t$ test for the value of English text writing skills between groups of students with different self-regulated learning obtained a significance value of $0.019(p<0.05)$, which means that there are significant differences in the value of English text writing skills between groups of students with low and high self-regulated learning. Table 4.5 in Group Statistics above also shows that students with low self-regulated learning have better English text writing skills than students with high self-regulated learning.

\section{Different Tests of Learning Methods on the Text Writing Skills for Students}

The results of hypothesis testing indicate that there are significant differences in Cooperative Integrated Reading and Composition (CIRC) in the form of text writing skills and through implementing Picture-Word Inductive Model (PWIM). The CIRC learning method has an average value of English text writing skills equal to 79.20 while students in the group that implements PWIM produce an average value 
of text writing skills amounted to 69.53. The differences in text writing skills between groups of students with the CIRC and PWIM learning methods indicate that the skills of writing texts between groups of students are influenced by the learning methods implemented. These findings indicate that CIRC is better than PWIM.

The results of this study are in line with Purwanti (2010) who suggested that the CIRC method can improve student learning activities. The increase in student learning activities is characterized by the achievement of the average percentage of the student's final learning ability test score result of more than $60 \%$. According to her, learning activities with methods that combine the ability to read and write make students become more interested in participating in learning so that they feel truly involved in the learning activities that have been discussed.

The results of this study are also supported by Wiranata's statement (2014) who states that the use of CIRC has a better influence on students' narrative essay writing abilities. This is because CIRC can encourage students to respond freely, cooperate and respect the opinions of others and create a cooperative learning atmosphere among fellow students and teachers so that it motivates students to interact and explore the topics of learning that exist, help each other, discuss and argue in expressing the idea.

Referring to the findings of this study and the support of previous research, it is expected that the mastery of students' English writing skills using the Cooperative Integrated Reading and Composition (CIRC) method is more improved, but does not rule out the possibility of implementing other methods so students are interested in learning in the classroom with happy and comfortable feelings. The existence of effectiveness in learning is important, in order to develop the knowledge of students and the achievement of learning outcomes.

\section{Discussion}

Implementation of Learning Methods and Levels of Self-Regulated Learning Students on Student Learning Outcomes

The results of hypothesis testing indicate that there are significant differences in Cooperative Integrated Reading and Composition (CIRC) in the form of text writing skills and through implementing Picture-Word Inductive Model (PWIM). The CIRC learning method has an average value of English text writing skills equal to 79.20 while students in the group that implements PWIM produce an average value of text writing skills amounted to 69.53. The differences in text writing skills between groups of students with the CIRC and PWIM learning methods indicate that the skills of writing texts between groups of students are influenced by the learning methods implemented. These findings indicate that CIRC is better than PWIM.

The results of this study are in line with Purwanti (2010) who suggested that the CIRC method can improve student learning activities. The increase in student learning activities is characterized by the achievement of the average percentage of the student's final learning ability test score result of more than $60 \%$. According to her, learning activities with methods that combine the ability to read and write make students become more interested in participating in learning so that they feel truly involved in the learning activities that have been discussed.

The results of this study are also supported by Wiranata's statement (2014) who states that the use of CIRC has a better influence on students' narrative essay writing abilities. This is because CIRC can encourage students to respond freely, cooperate and respect the opinions of others and create a cooperative learning atmosphere among fellow students and teachers so that it motivates students to interact and explore the topics of learning that exist, help each other, discuss and argue in expressing the idea.

Language learning with CIRC is able to provide significant writing learning outcomes (Slavin, et al. 1988; Durukan, 2011; Hadiwinarto \& Novianti, 2015; Gupta \& Ahuja, 2015; Varişoğlu, 2016), simultaneously encouraging cooperative learning for students in order to optimize their literacy skills. 
Furthermore, the implementation of CIRC according to Varişoğlu (2016) can also answer the problems that usually occur in traditional language teaching, such as the loss of students' interest in learning when teachers only pay attention to one student, which in turn decreases learning productivity. This is because CIRC provides a variety of activities that keep asking students to be active during learning (especially in the form of teams) and each student will have the opportunity to interact directly with the teacher in turns. $\mathrm{n}$ addition to being able to improve language skills, especially writing, all activities covered by CIRC are able to reflect attitudes and behaviors in cooperative learning that are very effective for students.

Through this CIRC, it can be seen that reading learning has relevance to writing learning, which according to Tuan (2012) both have reciprocal relationships that benefit one another. This is caused by the role of reading skills that can build a variety of knowledge and understanding to be written or in other words, become the basis of a writing, while writing can strengthen the knowledge of what is read. The advantage of the integration of reading and writing according to Chunhong Yang (2014) can be seen from the influence of reading skills that support students' writing skills; through reading, ideas on a particular topic will be more easily obtained and the idea becomes a source for developing a writing.

Referring to the findings of this study and the support of previous research, it is expected that the mastery of students' English writing skills using the Cooperative Integrated Reading and Composition (CIRC) method is more improved, but does not rule out the possibility of implementing other methods so students are interested in learning in the classroom with happy and comfortable feelings. The existence of effectiveness in learning is important, in order to develop the knowledge of students and the achievement of learning outcomes.

The results of the study showed significant differences in the value of English text writing skills between groups of students with low and high self-regulated learning. Table 4.5 in Group Statistics above also shown that students with low self-regulated learning have better English text writing skills than students with high self-regulated learning.

Zimmerman (2008) explained that in writing activities, self-regulated learning acts as a process of instruction and self-confidence that makes it easier for students to change their mental abilities, such as verbal skills, to become academic performance abilities. This also shows that students use proactive processes in improving their academic achievement. Proactive words are chosen, compared to the word reactive, to interpret the processes that students use in mastering academic abilities such as learning goals, selection and utilization of learning strategies, and self-monitoring of the effectiveness of their learning. In other words, student activity arises from itself. While reactive tends to describe the active attitude that arises not because of self-will but the influence/pressure of others.

As is known, writing does require a high level of self-regulation, related to planning, revision and use of strategies in writing (Graham et al. 2000). This is based on the explanation above which shows that self-regulated learning has an influence on academic ability, in this case writing skills, where students will consciously and responsibly activate themselves in order to achieve the mastery target (academic) that has been determined.

\section{Conclusion}

There are differences in English text writing skills between students who are taught through the CIRC method and students who are taught through the PWIM method. This shows that students' text writing skills are correctly influenced by the learning method implemented, where the CIRC method is better than PWIM in improving the writing skills. The research findings showed a significant difference in the value of English text writing skills between groups of students with low and high self-regulated learning. Wherein shown that students with low self-regulated learning have better English text writing skills than students with high self-regulated learning. 


\section{References}

Shafiee, S. \& Khavaran, S. R. (2017). Effects of Cooperative Learning on Vocabulary Achievement of Reflective/Impulsive Iranian EFL Learners. International Journal of Foreign Language Teaching \& Research, 5 (17).

Slavin, R. E. (1991). Synthesis of Research on Cooperative Learning. Educational Leadership, 48 (5), 71 82. Diakses dari http://www.ascd.org/ASCD/pdf/journals/ed_lead/el_199102_slavin.pdf.

Calhoun, E. F. (1999). Teaching Beginning Reading and Writing with the Picture Word Inductive Model. Alexandria: Association for Supervision and Curriculum Development.

Jiang, X. \& Perkins, K. (2013). A Conceptual Paper on the Application of the Picture Word Inductive Model Using Bruner's Conctructivist View of Learning and the Cognitive Load Theory. Interdisciplinary Journal of Teaching and Learning, 3 (1), 8-17.

Wiranata, A. (2014). Pengaruh Cooperative Integrated Reading and Composition terhadap Kemampuan Menulis Karangan Narasi Kelas V Sekolah Dasar. Program Studi Pendidikan Guru Sekolah Dasar, Jurusan Pendidikan Dasar FKIP Untan Pontianak. Diakses dari https://media.neliti.com/media/publications/215755-pengaruh-cooperative-integrated-reading.pdf

Slavin, R. E., Stevens, R. J. \& Madden, N. A. (1988). Accomodating Student Diversity in Reading and Writing Instruction, a Cooperative Learning Approach. Remedial and Special Education, 9 (1), 60-66.

Durukan, E. (2011). Effects of Cooperative Integrated Reading and Composition (CIRC) Technique on Reading-Writing Skill. Educational Research and Reviews, 6, 102-109.

Hadiwinarto \& Novianti. (2015). The Effects of Using CIRC Model on the English Learning Skills among Junior High School Students. Journal of Education and Learning, 9 (2), 117-124.

Gupta, M. \& Ahuja, J. (2015). Cooperative Integrated Reading Composition (CIRC): Improving Achievement in English Writing Composition among Seventh Graders. Issues and Ideas in Education, 3 (1), 49-53.

Varişoğlu, B. (2016). Influence of Cooperative Integrated Reading and Composition Technique on Foreign Students' Reading and Writing Skills in Turkish. Educational Research and Reviews, 11 (12), 1168-1179.

Tuan, L. 2012. Teaching Writing through Reading Integration. Journal of Language Teaching and Research, 3 (3), 489-499.

Chunhong Yang, Z. L. (2014). Reading-to-Write: A Practice of Critical Thinking. Journal of Arts and Humanities, 3 (5).

Zimmerman, B. J. (2008). Investigating Self-Regulation and Motivation: Historical Background, Methodological Developments, and Future Prospects. American Educational Research Journal, 45 (1), 166-183.

Graham, S., Harris, K., \& Troia, G. (2000). Self-Regulated Strategy Development Revisited: Teaching Writing Strategies to Struggling Writers. Topics in Language Disorders, 20 (2), 1-14. 


\section{Copyrights}

Copyright for this article is retained by the author(s), with first publication rights granted to the journal. This is an open-access article distributed under the terms and conditions of the Creative Commons Attribution license (http://creativecommons.org/licenses/by/4.0/). 